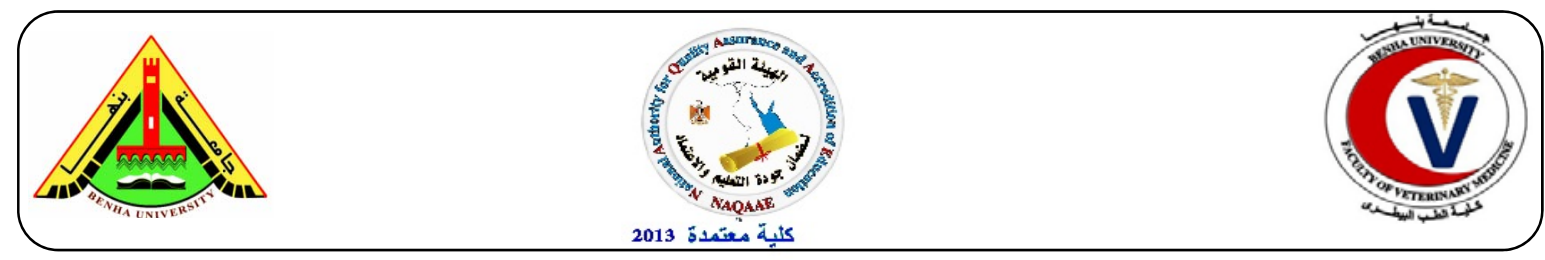

\title{
Biochemical alterations of inflammatory markers in experimentally induced diabetes in rats
}

\author{
El-Regily, A.F.Y. ${ }^{1}$; Abd El-Maksoud, H.A.A. ${ }^{2}$; El-Hindawy, U.M. ${ }^{1}$ and Sadek, K.M. ${ }^{1}$ \\ ${ }^{1}$ Department of Biochemistry, Faculty of Veterinary Medicine, Damanhour University. ${ }^{2}$ Department of \\ Biochemistry, Faculty of Veterinary Medicine, Benha University
}

\begin{abstract}
A B S T R A C T
This study was evaluated the protecting effect of rutin on the glycemic condition, lipid profile, in streptozotocin (STZ)-induced experimental diabetic in rats. With respect to an orally administrated rutin on serum glucose, the result is showing a significant decrease in glucose concentration when compared to diabetic group, While, a significant increase in insulin concentration when compared to diabetic. Moreover, the results revealed that, an administration of streptozotocin (STZ) showing significant increase in triacylglycerol, total cholesterol, LDL-c and VLDL-C concentration when compared with control group, while, showing significant decrease in HDL-C concentration and serum AST and ALT activity when compared to the control group. The data revealed also significant increase in serum LMDA concentration. While, significant decrease in serum calcium concentration when compared to the control group.
\end{abstract}

Keywords: Streptozotocin, Rutin, Glucose, Insulin, L-MDA, Calcium

(http://www.bvmj.bu.edu.eg)

(BVMJ-30(1): 29-38, 2016)

\section{INTRODUCTION}

$\mathrm{D}$ iabetes is a serious chronic disease worldwide and is caused by defects in insulin production, insulin secretion, and insulin signaling (Skyler, 2007). There are two types of diabetes: type 1 diabetes (T1D) is due to self-destruction of the insulin producing beta cells in the pancreas, and type 2 diabetes (T2D) is caused by defects in insulin action and insulin production (Cohen and Horton, 2007). The number of patients suffering from diabetes (DM) worldwide has increased rapidly over the past few years and for example it increased from 171 million people suffering from diabetes in 2000, to 382 million in 2013 and may reach to 592 million people by 2035 (IDF, 2013). Hyperglycemia is involved in the pathogenesis of diabetic neuropathy, retinopathy, nephropathy, and macro vascular disease via multiple mechanisms, of which increased aldose reductase activity
(Kato et al., 2003), nonenzymatic glycation and glycooxidation (Vlassara and Palace, 2003), activation of protein kinase C (PKC) (Way et al., 2001), and oxidativenitrosative stress (Pennathur and Heinecke, 2004). Also, diabetic patients with poor glycemic control are particularly at risk for developing associated pathologies described in humans and in animal models, such as cataracts, retinopathy, nephropathy, neuropathy, micro- and macro-vascular diseases, cardiomyopathy, and impaired tissue healing (Stirban et al., 2006). Oxidative stress resulting from enhanced free radical formation and/or a defect in antioxidant defenses has been implicated in the pathogenesis of experimental diabetic neuropathy. Reactive oxygen species (superoxide radical, hydrogen peroxide and hydroxyl radical) and reactive nitrogen species (peroxynitrite) contribute to pathophysiological changes in diabetic 
neuropathy (Vincent et al., 2004). Antioxidant enzyme defense system (superoxide dismutase, catalase and glutathione peroxidase) is also attenuated in peripheral nerves of diabetic animals indicating the vital role of oxidative stress in diabetic neuropathy (Low et al., 1997). Furthermore, diabetes mellitus is associated with an increased production of reactive oxygen species and a reduction in antioxidant defenses, which is partly responsible for diabetic complications, although some minerals and vitamins or cofactors, such as lipoic acid, are also able to exert antioxidant activity. The beneficial effects of $\alpha$-lipoic acid, both in the prevention and treatment of diabetes, have been suggested by different investigators (Haak et al., 2000) and at least one study indicates that $\alpha$-lipoic acid has beneficial effects on diabetic neuropathy partly due to its actions as an antioxidant and also by improving the circulation in the small blood vessels that supply nerve tissue (Packer et al., 2001). Protective effects of exogenously administered antioxidants have been extensively studied in animal models within recent years, thus providing some insight into the relationship between free radicals, diabetes, and its complications Maritim et al. (2003). Rutin is a common dietary flavonoid that possess a wide spectrum of biochemical and pharmacological actions attributed, at least partially, to their antioxidative and free-radical scavenging properties (Kampkotter et al., 2007). It is assumed to exert beneficial effects in various diseases including cancer, cardiovascular and neurodegenerative disorders (Williams et al., 2004). Rutin has potent antioxidant activity and is clinically used to treat diabetic neuropathy. Moreover, it enhances insulin-stimulated glucose disposal; to improve peripheral microcirculation and reduce neuropathic symptoms, possibly through attenuated oxidative stress (Vessal et al., 2003). Ozansoy and Akin (2004) recorded that, blood glucose, plasma triglyceride, cholesterol, low-density lipoprotein (LDL) cholesterol and thiobarbituric acid reactive substances (TEARS) levels were markedly increased in diabetic rats. Sri Balasubashini et al. (2003) recorded that, the levels of blood glucose and plasma triglycerides (TG), cholesterol and phospholipids were elevated during diabetes in rats induced with streptozotocin. Joice et al. (2008) observed that, significant increase in MDA levels and decrease in SOD activities were recorded in diabetic rats. The aim of this study was to evaluate the protecting effect of Rutin on the glycemic condition, lipid profile, in streptozotocin-induced diabetic in rats. Moreover, determination of its antioxidant effects on inflammatory markers in diabetes disease in rats.

\section{MATERIALS AND METHODS}

\subsection{Animals}

The study was carried out on 120 Male albino rats, aging (6-8 weeks) and of approximate weights ranging from (150$180 \mathrm{gm})$. The animals were purchased from "The Laboratory Animals Research Center", Faculty of Veterinary Medicine, Benha University. Rats were housed in separate wire mesh cages, exposed to good ventilation, humidity and to a 12-hr light/dark cycle. Provided with a constant supply of standard pellet diet (its composition is explained in table the below) and plenty of fresh, clean drinking water adlibitum. Rats were left for 15 days' adaptation period prior to the inception of experiment. And kept at constant environmental and nutritional conditions throughout the period of the experiment

\subsection{Chemicals and dosage:}

Physical properties: Rutin called also rutoside, quercetin-3-O-rutinoside and sophorin, is a citrus flavonoid glycoside between the flavonol quercetin and the disaccharide rutinose, with the molecular formula $\mathrm{C}_{27} \mathrm{H}_{30} \mathrm{O}_{16}$, molecular weight 450.27 , melting point $242^{\circ} \mathrm{C}$, yellowish powder and soluble in propylene glycol. Rutin (purity $\sim 99 \%$ ) was manufactured by 
EIPICO (Egyptian International Pharmaceutical Industries Company), $10^{\text {th }}$ of Ramadan City, Egypt. Preparation and dose of Rutin: Rutin was dissolved with in propylene glycol solution, (Tongjaroenbuangam et al., 2011), and administered to rats at a dose of $(200 \mathrm{mg} / \mathrm{kg}$ body weight) through oral intubation between 7 and 8 a.m. once a day for 45 days (Abdel-Raheem, 2010).

\subsection{Induction of diabetes:}

Rats were fasted for 18 hours and allowed free access of water. The experimental induction of diabetes in male rats was induced by a single intraperitoneal (i.p) injected dose of $50 \mathrm{mg} / \mathrm{kg}$ bw of Streptozotocin (STZ) (sigma Chemical Co. P.O. Box. 14508, St. Low is, U.S.A.) freshly dissolved in citrate buffer, $\mathrm{pH}$ 4.5. Control rats were received an equivalent amount of buffer alone. A week later, STZtreated rats were fasted for 12 hours, and blood samples were collected from the orbital venous sinus for glucose determination. Only those rats in diabetic group (group II) with blood glucose levels higher than $250 \mathrm{mg} / \mathrm{dl}$ were considered diabetic Baynes and Thorpe (1999). Streptozotocin (STZ) is widely used in experimental animal models to induce diabetes. Its cellular action includes irreversible changes in genetic material causing lethal alterations in the metabolism of cells Delfino et al. (2002).

\subsection{Animal grouping:}

Group I: Control group Included 20 of normal male rats. Group II: Diabetic rats "STZ group" A total number of 40 male diabetic rats kept in a separate metal. Diabetic rats were administered with propylene glycol only (diabetic control group). Group III: Rutin treated group: Diabetic rats were received Rutin was dissolved in propylene glycol and given alone at a dose of $(200 \mathrm{mg} / \mathrm{kg})$ body weight, orally through intra-gastric intubation, daily for 45 days.

\subsection{Sample Collection:}

At the end of the $15^{\text {th }}, 30^{\text {th }}$ and $45^{\text {th }}$ days of experimental period rats were fasted overnight, then, blood samples were collected from the retro-orbital venous plexus by heparinized capillary tubes. Blood samples were divided into two portions; the first portion was collected on EDTA anticoagulant. The rest of blood samples were collected in dry, clean test tubes and incubated for $1 / 2 \mathrm{hr}$ at room temperature to allow clotting for serum separation. Clear sera were separated by centrifugation at 3500 r.p.m. for 15 minutes and then collected in Eppendorf's tubes using automatic micropipettes. Part of serum samples were used immediately for measuring the activity of the following biochemical parameters: Alanine aminotransferase (ALT), Aspartate aminotransferase (AST), Glucose, and Insulin. The rest amount of the serum were kept in deep freezer at $\left(-20^{\circ} \mathrm{C}\right)$ for analysis of the remaining biochemical parameters. Determination of serum glucose (Trinder, 1969); insulin (Finlay and Dillard, 2007); total cholesterol (Allain et al., 1974); triacylglycerols (Fossati and Prencipe, 1982); HDL-C and LDL-C (Friedewald et al., 1972); VLDL-C (Bauer, 1982); Aspartate Aminotransferase (AST) and Alanine Aminotransferase (ALT) (Reitman and Frankel, 1957); L-Malondialdehyde LMDA (Ohkawa et al., 1979) and calcium (McLean and Hastings, 1935)

\subsection{Statistical analysis:}

The Statistical analysis was carried out using ANOVA (Steel et al. 1997).

\section{RESULTS}

\section{Serum glucose concentration ( $\mathrm{mg} / \mathrm{dl})$ :}

The data presented in Table (1) revealed that, an administration of Streptozotocin (STZ) showing significant increase in glucose concentration when compared. 
With respect to an orally administrated rutin on serum glucose, the result is showing a significant decrease in glucose concentration when compared to Diabetic group. Also, with respect to an orally administrated rutin on serum glucose, the result showing a significant increase in insulin concentration when compared to Diabetic. The data presented in Table (2) revealed that, an administration of Streptozotocin (STZ) showing significant increase in triacylglycerol, total cholesterol, LDL-c and VLDL-C concentration when compared with control group, while, showing significant decrease in HDL-C concentration when compared to the control group. Data in Table (2) showing a significant decrease in triacylglycerol, total cholesterol, LDL-C, concentration when compared to diabetic group. With respect to an orally administrated of rutin on HDL-C concentration. The result is showing a significant increase in HDL-C concentration when compared to Diabetic group. With respect to an orally administrated rutin on serum LDL-C concentration, the result showing a significant decrease in LDL-C concentration in when compared to diabetic group. With respect to an orally administrated a $0.2 \mathrm{ml}$ from the prepared solution at a dose $200 \mathrm{mg} / \mathrm{kg}$ b.w. of rutin on some plasma of Albino rats showing a significant difference decrease in VLDL-C concentration when compared to rutin treated diabetic rats with Diabetic group during all the period of the experiment.

The data presented in Table (3) revealed that, an administration of Streptozotocin (STZ) showing significant increase in serum AST and ALT activity when compared to the control group. With respect to an orally administrated rutin showing a significant decrease in serum AST and ALT activities when compared to diabetic group. The data presented in Table (3) revealed that, an administration at of Streptozotocin (STZ) showing significant increase in serum L-MDA concentration when compared to the control group. While, showing significant decrease in serum calcium concentration when compared to the control group.

Table (1): The effect of STZ and or rutin on serum glucose and insulin (mean \pm S.E.)

\begin{tabular}{|c|c|c|c|c|}
\hline \multirow[b]{2}{*}{ Parameter } & \multirow[b]{2}{*}{$\begin{array}{l}\text { Duration } \\
\text { (day) }\end{array}$} & \multicolumn{3}{|c|}{ Group } \\
\hline & & $\begin{array}{l}\text { Control } \\
\text { (G1) }\end{array}$ & $\begin{array}{c}\text { Experimental } \\
\text { Diabetes } \\
\text { (G2) }\end{array}$ & $\begin{array}{l}\text { Rutin treated diabetic rats } \\
\qquad \text { (G3) }\end{array}$ \\
\hline \multirow{4}{*}{ Glucose (mg/dl) } & 0 & $85.13 \pm 1.93^{\mathrm{C}}$ & $202.3 \pm 6.17^{\mathrm{A}}$ & $140.13 \pm 3.27^{\mathrm{B}}$ \\
\hline & 15 & $89.37 \pm 2.78^{\mathrm{g}}$ & $170.88 \pm 1.15^{\mathrm{c}}$ & $155.04 \pm 2.06^{\mathrm{d}}$ \\
\hline & 30 & $81.16 \pm 1.46^{\mathrm{g}}$ & $189.12 \pm 1.66^{\mathrm{b}}$ & $146.91 \pm 1.42^{\mathrm{e}}$ \\
\hline & 45 & $84.86 \pm 0.95^{\mathrm{g}}$ & $246.9 \pm 1.39^{\mathrm{a}}$ & $118.45 \pm 0.92^{\mathrm{f}}$ \\
\hline \multirow{4}{*}{$\begin{array}{l}\text { Insulin } \\
(\mathrm{mg} / \mathrm{dl})\end{array}$} & 0 & $17.01 \pm 0.4^{\mathrm{A}}$ & $7.89 \pm 0.17^{\mathrm{C}}$ & $9.89 \pm 0.28^{\mathrm{B}}$ \\
\hline & 15 & $15.21 \pm 0.48^{\mathrm{b}}$ & $8.37 \pm 0.19^{\text {de }}$ & $9.75 \pm 0.29^{\mathrm{cd}}$ \\
\hline & 30 & $18.33 \pm 0.16^{\mathrm{a}}$ & $7.61 \pm 0.15^{\mathrm{e}}$ & $10.25 \pm 0.27^{\mathrm{c}}$ \\
\hline & 45 & $17.5 \pm 0.27^{\mathrm{a}}$ & $7.68 \pm 0.16^{\mathrm{e}}$ & $9.69 \pm 0.3^{\mathrm{cd}}$ \\
\hline
\end{tabular}


Table (2): The effect of STZ and or rutin on serum lipid profile (mean \pm S.E.)

\begin{tabular}{|c|c|c|c|c|}
\hline \multirow[b]{2}{*}{ Parameter } & \multirow[b]{2}{*}{$\begin{array}{c}\text { Duration } \\
\text { (day) }\end{array}$} & \multicolumn{3}{|c|}{ Group } \\
\hline & & $\begin{array}{l}\text { Control } \\
\text { (G1) }\end{array}$ & $\begin{array}{c}\text { Experimental } \\
\text { Diabetes } \\
\text { (G2) }\end{array}$ & $\begin{array}{c}\text { Rutin treated } \\
\text { diabetic rats } \\
\text { (G3) }\end{array}$ \\
\hline \multirow{5}{*}{ Triacylglycerol (TG) (mg/dl) } & 0 & $107.10 \pm 1.47^{\mathrm{B}}$ & $226.98 \pm 6.44^{\mathrm{A}}$ & $105.83 \pm 2.37^{\mathrm{B}}$ \\
\hline & 15 & $103.40 \pm 1.04^{\mathrm{f}}$ & $192.65 \pm 1.55^{\mathrm{c}}$ & $117.70 \pm 1.45^{\mathrm{d}}$ \\
\hline & 30 & $105.26 \pm 1.43^{\mathrm{ef}}$ & $215.8 \pm 2.15 b$ & $108.49 \pm 1.33^{\mathrm{ef}}$ \\
\hline & 45 & $112.63 \pm 1.45^{\mathrm{de}}$ & $272.48 \pm 1.28^{\mathrm{a}}$ & $91.30 \pm 0.99^{\mathrm{g}}$ \\
\hline & 0 & $96.98 \pm 1.40^{\mathrm{C}}$ & $242.35 \pm 7.63^{\mathrm{A}}$ & $157.22 \pm 3.32^{\mathrm{B}}$ \\
\hline \multirow{3}{*}{ Total cholesterol (TC) (mg/dl) } & 15 & $93.64 \pm 0.87^{\mathrm{h}}$ & $197.48 \pm 1.07^{\mathrm{c}}$ & $174.09 \pm 1.02^{\mathrm{d}}$ \\
\hline & 30 & $95.34 \pm 1.20^{\mathrm{gh}}$ & $234.26 \pm 2.00^{\mathrm{b}}$ & $162.14 \pm 1.73^{\mathrm{e}}$ \\
\hline & 45 & $101.96 \pm 1.64^{\mathrm{g}}$ & $295.31 \pm 1.35^{\mathrm{a}}$ & $135.43 \pm 1.56^{\mathrm{f}}$ \\
\hline \multirow{5}{*}{ HDL-C (mg/dl) } & 0 & $39.85 \pm 1.38^{\mathrm{B}}$ & $24.17 \pm 0.75^{\mathrm{C}}$ & $45.54 \pm 1.05^{\mathrm{A}}$ \\
\hline & 15 & $37.88 \pm 1.83^{\mathrm{b}}$ & $23.76 \pm 0.89^{c}$ & $48.31 \pm 1.09^{\mathrm{a}}$ \\
\hline & 30 & $40.76 \pm 1.14^{\mathrm{b}}$ & $24.51 \pm 0.73^{\mathrm{c}}$ & $47.41 \pm 0.71^{\mathrm{a}}$ \\
\hline & 45 & $40.93 \pm 1.14^{\mathrm{b}}$ & $24.24 \pm 0.71^{\mathrm{c}}$ & $40.90 \pm 0.83^{b}$ \\
\hline & 0 & $32.48 \pm 1.16^{\mathrm{C}}$ & $97.85 \pm 3.22^{\mathrm{A}}$ & $55.91 \pm 1.73^{\mathrm{B}}$ \\
\hline LDL-C & 15 & $33.39 \pm 1.07^{\mathrm{f}}$ & $82.72 \pm 0.76^{\mathrm{c}}$ & $49.86 \pm 1.27^{\mathrm{e}}$ \\
\hline \multirow[t]{3}{*}{$(\mathrm{mg} / \mathrm{dl})$} & 30 & $31.92 \pm 1.35^{\mathrm{f}}$ & $92.54 \pm 2.69^{b}$ & $52.31 \pm 1.18^{\mathrm{e}}$ \\
\hline & 45 & $32.14 \pm 1.14^{\mathrm{f}}$ & $118.28 \pm 0.77^{\mathrm{a}}$ & $65.55 \pm 1.15^{\mathrm{d}}$ \\
\hline & 0 & $21.33 \pm 0.66^{\mathrm{B}}$ & $45.02 \pm 1.54^{\mathrm{A}}$ & $20.90 \pm 1.01^{\mathrm{B}}$ \\
\hline VLDL-C & 15 & $22.09 \pm 0.94^{\mathrm{de}}$ & $37.66 \pm 1.02^{\mathrm{c}}$ & $23.43 \pm 1.09^{\mathrm{d}}$ \\
\hline \multirow[t]{2}{*}{$(\mathrm{mg} / \mathrm{dl})$} & 30 & $21.22 \pm 0.61^{\mathrm{de}}$ & $44.06 \pm 0.77^{\mathrm{b}}$ & $20.88 \pm 1.07^{\mathrm{de}}$ \\
\hline & 45 & $20.69 \pm 0.35^{\mathrm{de}}$ & $53.34 \pm 1.18^{\mathrm{a}}$ & $18.40 \pm 0.69^{\mathrm{e}}$ \\
\hline
\end{tabular}

Table (3): The effect of STZ and or rutin on serum AST, ALT, L-MDA and calcium activities (mean $\pm \mathrm{SE}$ ).

\begin{tabular}{|c|c|c|c|c|}
\hline \multirow[b]{2}{*}{ Parameter } & \multirow[b]{2}{*}{ Duration (day) } & \multicolumn{3}{|c|}{ Group } \\
\hline & & $\begin{array}{l}\text { Control } \\
\text { (G1) }\end{array}$ & $\begin{array}{c}\text { Experimental } \\
\text { Diabetes } \\
(\mathrm{G} 2)\end{array}$ & $\begin{array}{l}\text { Rutin treated diabetic rats } \\
\qquad(\mathrm{G} 3)\end{array}$ \\
\hline \multirow{4}{*}{$\begin{array}{c}\text { AST } \\
\text { activity } \\
(\mathrm{U} / 1)\end{array}$} & 0 & $80.75 \pm 1.11^{\mathrm{C}}$ & $123.22 \pm 1.99^{\mathrm{A}}$ & $90.38 \pm 1.74^{\mathrm{B}}$ \\
\hline & 15 & $78.11 \pm 1.11^{\mathrm{d}}$ & $118.84 \pm 1.93^{\mathrm{b}}$ & $94.13 \pm 0.86^{\mathrm{c}}$ \\
\hline & 30 & $81.24 \pm 0.96^{\mathrm{d}}$ & $124 \pm 2.04^{\mathrm{ab}}$ & $95.73 \pm 1.17^{\mathrm{c}}$ \\
\hline & 45 & $82.9 \pm 1.18^{\mathrm{d}}$ & $126.81 \pm 1.93^{\mathrm{a}}$ & $81.3 \pm 1.75^{\mathrm{d}}$ \\
\hline \multirow{4}{*}{$\begin{array}{c}\text { ALT } \\
\text { activity } \\
(\mathrm{U} / 1)\end{array}$} & 0 & $100.29 \pm 1.9^{\mathrm{C}}$ & $153.82 \pm 5.15^{\mathrm{A}}$ & $119.27 \pm 2.07^{\mathrm{B}}$ \\
\hline & 15 & $96.79 \pm 1.12^{\mathrm{e}}$ & $130.35 \pm 2.47^{\mathrm{c}}$ & $118.85 \pm 1.93^{\mathrm{d}}$ \\
\hline & 30 & $101.74 \pm 2.43^{\mathrm{e}}$ & $143.71 \pm 2.7^{\mathrm{b}}$ & $115.46 \pm 1.74^{\mathrm{d}}$ \\
\hline & 45 & $102.34 \pm 1.95^{\mathrm{e}}$ & $187.41 \pm 2.5^{\mathrm{a}}$ & $123.5 \pm 2.43^{\mathrm{cd}}$ \\
\hline \multirow{4}{*}{ L-MDA (mg/dl) } & 0 & $5.02 \pm 0.15^{\mathrm{B}}$ & $8.28 \pm 0.23^{\mathrm{A}}$ & $4.72 \pm 0.19^{\mathrm{B}}$ \\
\hline & 15 & $4.92 \pm 0.16^{\mathrm{d}}$ & $6.98 \pm 0.11^{\mathrm{c}}$ & $5.2 \pm 0.13^{\mathrm{d}}$ \\
\hline & 30 & $5.01 \pm 0.18^{\mathrm{d}}$ & $8.47 \pm 0.16^{\mathrm{b}}$ & $5.24 \pm 0.12^{\mathrm{d}}$ \\
\hline & 45 & $5.14 \pm 0.13^{\mathrm{d}}$ & $9.39 \pm 0.15^{\mathrm{a}}$ & $3.71 \pm 0.15^{\mathrm{e}}$ \\
\hline \multirow{4}{*}{ Calcium (mg/dl) } & 0 & $8.29 \pm 0.11^{\mathrm{B}}$ & $6.03 \pm 0.22^{\mathrm{C}}$ & $9 \pm 0.18^{\mathrm{A}}$ \\
\hline & 15 & $8.27 \pm 0.12^{\mathrm{cd}}$ & $5.2 \pm 0.11^{\mathrm{e}}$ & $8.56 \pm 0.17^{\mathrm{bc}}$ \\
\hline & 30 & $8.27 \pm 0.12^{\mathrm{cd}}$ & $7.59 \pm 0.09^{d}$ & $9.29 \pm 0.18^{\mathrm{a}}$ \\
\hline & 45 & $8.32 \pm 0.11^{\mathrm{c}}$ & $5.3 \pm 0.08^{\mathrm{e}}$ & $9.15 \pm 0.19^{\mathrm{ab}}$ \\
\hline
\end{tabular}




\section{DISCUSSON}

The results revealed that, I.P. injection of STZ to male albino rats induced pathophysiological symptoms as occur in experimental diabetic rats. Myers et al. (1990) who reported that, serum glucose levels was elevated three-fold in the diabetic animals group compared to normal. In contrary, (Ogihara et al., 1984) reported that, in streptozotocin (STZ)-diabetic rats, the plasma glucose concentration decreased gradually during prolonged starvation, while it did not change in normal rats. Our results showed a significant decrease in plasma insulin concentration was observed in streptozotocin-induced diabetic rats allover the periods of the experiments. These results are nearly similar to those reported by Vinik and Vinik (2003) who reported that, high levels of circulating glucose and FFA found in type II diabetic patients are toxic to $\beta$-cells. Prolonged hyperglycemia in individuals with diabetes causes not only $\beta$-cell dysfunction but also decreased $\beta$-cell mass due to induction of apoptosis. Our results showed a significant increase in plasma glucose concentration was observed in streptozotocin-induced diabetic rats allover the periods of the experiments. These results are nearly similar to those reported by Yimaz et al. (2004) reported that glucose concentration in the blood plasma of streptozotocintreated rats was significantly higher than in the normal control group. Our results showed a high significant increase in group two diabetic rats at 15, 30 and 45 days and significant increase in group 3 Rutin treated diabetic rats at 15 and 30 days. Our results showed a high significant decrease in plasma insulin concentration was observed in group two diabetic rats at 15, 30 and 45 days. Furthermore, the increased presence of circulating fatty acids in combination with hyperglycemia has also been implicated in the induction of $\beta$-cell apoptosis, resulting in decreased $\beta$-cell mass and function. Moreover, (Robertson, 2004) reported that, diabetes mellitus comprises a group of chronic diseases characterized by hyperglycaemia or diminished insulin secretion or both and profound effects on lipid metabolism. The obtained data revealed that, a significant increase in plasma triacylglycerols concentration was observed in streptozotocin induced diabetic rats in group two diabetic rats after 15 days, and a high significant increase after 30 and 45 days. The pronounced increase in Plasma cholesterol levels in diabetic rats is in agreement with results reported previously by Black et al. (1993) observed that, glucose, triglyceride, and cholesterol concentrations were significantly elevated in streptozocin (STZ)-induced $(55 \mathrm{mg} / \mathrm{kg}$ intravenously [IV]) diabetic male Wistar rats.

In contrary, (Nishida et al., 2002) observed that, the untreated diabetic rats had the increased plasma levels of triglycerides, cholesterol, insulin and leptin at $35 \mathrm{wk}$, as compared with the healthy control rat. Our results revealed that, a significant increase in plasma total cholesterol concentration was observed in streptozotocin- induced diabetic rats after 15 days and a high significant increase in plasma total cholesterol concentration was observed after 30 and 45 days of the experiments in group two diabetic rats and a significant increase in group three after 15 days. Hypercholesterolemia is common in diabetes, contributing to the high prevalence of coronary heart disease (Ali et al., 2004). Also, (Nishida et al., 2002) observed that, the untreated diabetic rats had the increased plasma levels of triglycerides, cholesterol, insulin and leptin at $35 \mathrm{wk}$, as compared with the healthy control rat. Moreover, (Thirunavukkarasu et al., 2004) reported that, streptozotocininduced diabetes increases TC, LDL-C, and triglycerides as well as decreases HDL-C concentrations. The mechanism is possibly due to reduction in lipoprotein lipase activity secondary to reduced plasma insulin levels. Cholesteryl ester transfer protein, which is important in regulating 
lipoprotein lipid composition was increased in DM condition and may also contributed to the dyslipidemia Wasan et al. (1998). Hypertriglyceridemia is a common metabolic disorder associated with STZinduced diabetes (Nielsen et al., 2002). The pronounced increase in plasma triglycerides levels in diabetic rats is in agreement with results reported previously by Ahmed et al. (2001) showed that, there was a significant increase in plasma non-esterified cholesterol, triglycerides and phospholipids in STZ-induced diabetic rats, accompanied by a decrease in high density lipoprotein (HDL)-cholesterol. Furthermore, (Anandh Babu et al., 2006) reported that, there was an increase in the serum and cardiac triglyceride levels in diabetic rats. The reported changes in TG could be related to the mild but significant insulin deficiency resulted in mild hypertriglyceridemia, linked to impaired triglyceride removal rather than to an overproduction of VLDLtriglyceride, despite elevated levels of plasma free fatty acids. Also it could be attributed to the disturbed tissue lipases system which regulated by insulin were suppressed by STZ increasing TG (Gorska et al., 1990). This suggestion was confirmed by Yoshino et al. (1992) who suggested that, the removal of triglyceride from the circulation, as well as its entry into the circulation, was impaired in mildly insulindeficient rats. Our results revealed that serum HDL-concentration decreased significantly after 30 and 45 days. Our results revealed that, a high significant increase in plasma LDL- concentration was observed in streptozotocin induced diabetic rats in group two diabetic rats after 30 and 45 days, and a significant increase after 15 days. A significant increase in Serum transaminases enzymes (AST and ALT) activities was observed in streptozotocininduced diabetic rats allover the periods of the experiments. These results are nearly similar to those reported by Mohammad et al. (2006) who showed that, the aminotransferases (AST and ALT) levels were significantly increased in the liver of
STZ-treated animals. The increase in aminotransferases levels may be due to the cellular damage in the liver caused by STZinduced diabetes. Moreover, (Voss et al., 1988) proposed that STZ in hyperglycemic animals caused a time dependent rise in AST, ALT, and ALP levels. In contrary, (Okada et al., 1997) reported that, AST activity was lower than the amount of enzyme in diabetic rat tissues. It is suggested that this may be due to the inactivation of cytosolic AST in the diabetic rat tissues by a glycation reaction, accompanied by impairment in glucose utilization in STZ induced diabetes.

Many workers explained the observed reduction of serum $\mathrm{Ca}^{+2}$ level in diabetics to be due to reduction in duodenal $\mathrm{Ca}^{+2}$ transport (Schneider and Schedl, 1972) or impaired renal reabsorption of $\mathrm{Ca}^{+2}$ Cheug (1980). Our results showed a significant increase in serum L-malondialdehyde concentration was observed in streptozotocin-induced diabetic rats allover the periods of the experiments. These results are nearly similar to those reported by Sundaram et al. (1996) who demonstrated that, plasma MDA showed 80 $\%$ increase in the early stages of diabetes, and more progressive increase later which explained as the factors favouring the formation of reactive oxygen species may catalyze lipid peroxidation in the plasma and other tissues and in poorly controlled diabetic, glucose oxidation through the pentose phosphate pathway initiates excessive formation of NADPH, this in turn can promote lipid peroxidation in the presence of cytochrome P- 450 system. The recorded results could be related to the inactivation or inhibition of antioxidant enzymes through glycation, in poorly controlled diabetes mellitus, may give rise high lipid peroxidation rate, evidence of lipid peroxidation had been observed in many diabetic complications increased level of plasma lipid peroxidation products, measured a thiobarbituric acid reactive substance, have been found to be higher in diabetes and the most harmful free 
radical are unpaired oxygen (stable molecules contain paired electrons), hydroperoxides and superoxide anions (Diplock, 1994). Malondialdehyde (MDA) formed by the breakdown of oxidized polyunsaurated fatty acids, has been considered as a marker of the free oxygen radical formation in red blood cells (RBCs) of diabetic patient and alloxan diabetic rats and the hyperglycemia can accelerate lipid peroxidation of human (RBCs) Awaji et al. (1995).

\section{REFERENCES}

Abdel-Raheem, I.T. 2010. Gastroprotective Effect of Rutin against IndomethacinInduced Ulcers in Rats. Basic and Clinical Pharmacology and Toxicology, 107: 742-750.

Ahmed, I.; Lakhani, M.S.; Gillett, M.; John, A. and Raza, H. 2001. Hypotriglyceridemia and hypo-cholestrolemic effects of antidiabetic Momordica charantia (karela) fruit extract in streptozotocin- induced diabetic rats. Diabetes Res. Clin. Pract., 51(3): 155-161.

Ali, M.M. and El Kader, M.A. 2004. The influence of naringin on the oxidative state of rats with streptozotocin-induced acute hyperglycaemia. Z. Naturforsch [C]. Sep- Oct; 59 (9-10): 729-733.

Allain, C.C.; Poon, L.S.; Chan, C.S.; Richmond, W. and $\mathrm{Fu}$, P.C. 1974. Enzymatic determination of total serum cholesterol. Clin. Chem., 4: 470-475.

Anandh Babu, P.V.; Sabitha, K.E. and Shyamaladevi, C.S. 2006. Green tea extract impedes dyslipidaemia and development of cardiac dysfunction in streptozotocin- diabetic rats. Clinical and Experimental Pharmacology and Physiology, 33: 1184-1189.

Bauer, J.D. 1982: "Clinical laboratory methods" 9th Ed, the C.V. Company Waistline Industrial Missouri 63116 Chapter 33, p.555.

Baynes, J.W. and Thorpe, S.R. 1999. Role of oxidative stress in diabetic complications: A new perspective on an old paradigm. Diabetes, 48: 1-9.

Black, S.C.; Katz, S. and Me Neill, J.H. 1993. Influence of omega-3 fatty acid treatment on cardiac phospholipid composition and coronary flow of streptozocin-diabetic rats. Metabolism, 42(3): 320-326.

Cohen, A. and Horton, E.S. 2007. Progress in the treatment of type 2 diabetes: new pharmacologic approaches to improve glycemic control. Curr. Med. Res. Opin., 23: 905-917.

Diplock, A.T. 1994: Antioxidations and disease prevention. Molec. Aspects. Med. 15: $295-376$.

Finlay, J.W.A. and Dillard, R.F. 2007. Appropriate Calibration CurveFitting in Ligand Binding Assays. AAPS J., 9(2): E260-E267.

Fossati, P. and Prencipe, L. 1982. Serum triacylglycerols determined calorimetrically with an enzyme that produces hydrogen peroxide. Clin. Chem., 1: 2077-2080.

Friedewald, W.T. 1971. Colorimetric method for determination of cholesterol LDL activity.

Haak, E.; Usadel, K.H.; Frommeyer, R. and Tritschler, H.J. 2000. Effects of alphalipoic acid on microcirculation in patients with peripheral diabetic neuropathy. Exp. Clin. Endocrinol. Diabetes, 108: 168174.

IDF 2013. International Diabetes Federation. IDF Diabetes Atlas, $6^{\text {th }}$ Edn. Brussels, Belgium. Available at: http://www.idf.org/ diabetesatlas.

Joice, M.C.; Corinne and Calcutt, A.P. 2008: Elvated lipid peroxidation and DNA oxidation in nerve from diabetic rats; effects of aldose reductase inhibition, insulin, and neurotrophic factors. Metabolism Clinical Experimental, 57: 873-881.

Kampkotter, A.; Nkwonkam, C.G.; Zurawski, R.F.; Timpel, C.; Chovolou, Y.; Watjen, W.; Kahl, R. 2007. Investigations of protective effects of the flavonoids quercetin and rutin on stress resistance in the model organism Caenorhabditis elegans. Toxicology, 234: 113-123.

Kato, N.; Yashima, S.; Nakayama, V. and Jomori, T. 2003. Long-term treatment with fidarestat suppresses the development. of diabetic retinopalhy in STZ-induced diabetic rats. J. Diabetes Complications, 17: 374-379.

Low, P.A.; Nickander, K.K. and Tritschler, H.J. 1997. The role of oxidative stress and 
antioxidant treatment in experimental diabetic neuropathy. Diabetes, 46: 3842.

Maritim, A.C.; Sanders, R.A. and Watkins III, J.B. 2003. Diabetes, Oxidative Stress, and Antioxidants: A Review. J. Biochem. Mol. Toxicol., 17: 24-38.

McLean, F.C. and Hastings, A.B. 1935. Thestate of calcium in the fluids of the bodyThe conditions affecting theionization of calcium. J. Biol. Chem., 108: 285-322

Myers, S.I; Bartula, L.; LInzel, M.; phan, T.; Jung, P.J. and Merrell, R.C. 1990. The effect of diabetes mellitus on aortic portioned synthesis and serum cholesterol levels in the rat fed a high cholesterol diet. Life. Sci., 47(6): 587594.

Nielsen, K.; Serup, P.; Mandrup-Paulsen, T. and Nerup, J. 2002: B cell maturation leads to in vitro sensitivity to cotoxins. Diabetes. 48: $2324-2332$.

Nishida, S.; Segawa, T.; Murai, I. and Nakagawa, S. 2002. Long- term melatonin administration reduces hyperinsulinrmia and improves the altered fatty - acid compositions in type 2 diabetity. J. Pineal. Res., 32(1): 26 -33.

Ogihara, M.; Tokumitsu, Y. and Ui, M. 1984. Metabolic alterations in normal and streptozotocin-diabetic rats in vivo: influence of prolonged starvation. Jpn. J. Pharmacol., 34(3): 307-311.

Ohkawa, H.; Onishi, N. and Yagik 1979. Assay for lipid peroxides in animal tissue by thiobabituric acid reaction. Anal. Biochem., 95: 351-8.

Okada, M.; Murakami, Y. and Miyomoto, E. 1997. Glycation and inactivation of aspartate aminotransferase in diabetic rat tissues. Nutritional Science and Vitaminology. 43(4): 463-469.

Ozansoy, G. and Akin, F.B. 2004. Effects of gemfibrozil treatment on vascular reactivity of streptozotocin-diabetic rat aorta. J. Pharm. Pharmacol., 56(2): 241246.

Packer, L.; Kraemer, K. and Rimbach G. 2001. Molecular aspects of lipoic acid in the prevention of diabetes complications. Nutrition, 17: 888-895.

Pennathur, S. and Heinecke, J.W. 2004. Mechanisms of oxidative stress in diabetes: implications for the pathogenesis of vascular disease and antioxidant therapy. Front. Biosci., 9: 565-574.

Rajagopal, K. and Sasikala, K. 2008. Antihyperglycaemic and antihyperlipidaemic effects of Nyphaea tellata in alloxan induced diabetic rats. Singapore Med. J., 49(2): 137:141.

Reitman, S. and Frankel, S. 1957. Acolorimetric method for the determination of serum glutamate oxaloacetic and glutamate Pyruvic transaminases. Amerrican J. Clinical Pathology, 28(1): 56-63.

Reitmans, S. and Frankel, S. 1957. ReitmanFrankel colourimetric method of Got/ As $\mathrm{T}$ and GPT/ALT Tromsaminales. Am. J. Clin. Path. 28: 56-63.

Robertson R.P. 2004. Chronic oxidative stress: a central mechanism for glucose toxicity in pancreatic islet beta cell in diabetes. J. Biol. Chem., 279: 4235-2354.

Sayyed, S.G.; Kumar, A. and Sharma, S.S. 2006. Effects of US3836E on nerve functions, hypcralgesia and nxidative stress in experimental diabetic neuropathy. Life Sci., 79: 777-783.

Skyler, J.S. 2007. Prediction and prevention of type 1 diabetes: progress, problems, and prospects. Clinical Pharmacology and Therapeutics, 8: 768-771.

Sri Balasubashini, M.; Rukkumani, R. and Menon, V.P. 2003. Protective effects of ferulic acid on hyperlipidemic diabetic rats. Acta. Diabetol., 40(3): 118 - 122.

Steel, R.G.D.; Torrie, J.H. and Dickcy, D.A. 1997. Principles and procedures of statistics. A Biometrical Approach. $3^{\text {rd }}$ Ed., McGraw-Hill, New York.

Stirban, A.; Negrean, M. and Tschoepe, D. 2006. Benfotiamine prevents macro-and microvascular endothelial dysfunction and oxidative stress following a meal rich in advanced glycation end products in individuals with type 2 diabetes. Diabetes Care, 29: 2064-2071.

Sundaram, R.K.; Bhaskar, A. and Mohan, R. 1996. Antioxidant status and lipid peroxidation in type II diabetes mellitus with and without complications. Clin. Sci. (Lond), 90: 255-260.

Thirunavukkarasu, V.; Anita Nandhini, A.T. and Arunadha C.Y. 2004. Effects of alpha lipoic acids in rats fed a high- 
fructose diet. Experimental Diabesity Research 5(3):195-200.

Tongjaroenbuangam, W.; Ruksee, N.; Chantiratikul, P.; Pakdeenarong, N.; Kongbuntad, W. and Govitrapong, P. 2011. Neuroprotective effects of quercetin, rutin and okra (Abelmoschus esculentus Linn.) in dexamethasonetreated mice. Neurochemistry International.

Trinder, P. 1969. Determination of glucose in blood using glucose oxidase with an alternative oxygen acceptor. Ann. Clin. Biochem. 6: 24-32.

Uhad, A. and Chopra, K. 2009a. Attenuation of diabetic nephropathy by tocotrienol:involvement of $\mathrm{NF}_{\mathrm{k}} \mathrm{B}$ signaling pathway. Life Sci., 84: 296 301.

Vessal, Hemmati M. and Vasie M. 2003. Antidiabetic effects of quercetinin in streptozotocin-induced diabetic rats. Comp Biochem. Physiol. C. Toxicol. Pharmacol., 135: 357-364.

Vincent, A.M.; Russel, J.W.; Low, P. and Feldman, E.L. 2004. Oxidative stress in the pathogenesis of diabetic neuropathy. Endocr Rev., 25: 612-628.

Vlassara, H.; and Palace, M.R. 2003. Glycoxidation: The menace of diabetes and aging. Mt. Sinai. J. Med., 60: 232241.

Wasan, K.M.; Ng, S.P.; Wong, W. and Rodrigues, B.B. 1998. Streptozotocinand alloxan -induced diabetes modifies total plasma and lipoprotein lipid concentration and composition without altering cholesteryl ester transfer activity. Pharmacol. Toxicol., 83: 169-175.

Way, K.J.; Katai, N. and King, G.L. 2001. Protein kinase $\mathrm{C}$ and the development of diabetic vascular complications. Diabetes Med., 18: 945-959.

Williams, R.J.; Spencer, J.P. and Rice-Evans, C. 2004. Flavonoids: antioxidants or signalling molecules? Free Radic. Biol. Med., 36: 838-849.

Yimaz, H.R; Uz, E.; Yucel, N.; Altuntas, I. and Ozcelik N. 2004. Protective effect of caffeic acid phenethyl ester (CAPE) on lipid peroxidation and antioxidant enzymes in diabetic rat liver. J. Biochem. Mol. Toxicol., 18: 234-8.

Yoshino, G.; Matsushita, M.; Iwai, M. and Morita, M. 1992. Effect of mild diabetes and dietary fructose on very-low-density lipoprotein triglyceride turnover in rats. Metabolism., 41(3): 236-240. 